\title{
Other Dark Sides of Resilience: Politics and Power in Community-Based Efforts to Strengthen Resilience
}

\section{Siobhan McDonnell}

To cite this article: Siobhan McDonnell (2019): Other Dark Sides of Resilience: Politics and Power in Community-Based Efforts to Strengthen Resilience, Anthropological Forum, DOI: 10.1080/00664677.2019.1647828

To link to this article: https://doi.org/10.1080/00664677.2019.1647828

曲 Published online: 08 Aug 2019.

Submit your article to this journal $₫$

Џ Article views: 149

Q View related articles $\widetilde{ }$

View Crossmark data $\asymp$ 


\title{
Other Dark Sides of Resilience: Politics and Power in Community-Based Efforts to Strengthen Resilience
}

\author{
Siobhan McDonnell \\ Crawford School of Public Policy, Australian National University, Canberra, Australia
}

\begin{abstract}
Oceanic people and places are increasingly labelled as either 'resilient' or 'vulnerable' to disasters and climate change. Resilience is often described in disaster discourse as a strategy designed to overcome vulnerability by helping communities to 'bounce back' in the wake of 'natural' disasters. Using ethnographic research conducted with Community Disaster and Climate Change Committees (CDCs) in Vanuatu in the wake of Tropical Cyclone Pam, this paper seeks to problematise disaster responses that see the 'community' as a space to be acted upon by outsiders, or where people will respond in a unified way to the challenges of rebuilding after disaster. Using political ecology framings this paper critiques the ideas of resilience that appear entrenched in community-based disaster and climate change adaptation discourse and practice in Oceania. Rather than presupposing resilience or vulnerability, this paper details the dispersal and distribution power and agency amongst individual actors and groups that either supported or manipulated, the distribution of goods by Community Disaster Committees. In this way, it moves beyond the limitations of conceptual framings of resilience in disaster management and climate change into a more considered appraisal of power, by exploring what James Ferguson has termed 'the politics of distribution' in the context of disaster.
\end{abstract}

\section{KEYWORDS}

Disaster; resilience; vulnerability; Pacific; climate change

Oceanic people and places are increasingly labelled as either 'resilient' or 'vulnerable' to disasters and climate change. This is particularly true of island states, which are often framed by narratives of 'sinking' which are, in turn, powerfully resisted by Oceanic activists who offer the battle cry: 'We are not drowning. We are fighting' (350 Pacific 2013; Kelman 2018). It is a necessary battle cry, as across Oceania countries are experiencing the dramatic impacts associated with climate change. These include an increase in extreme weather events, sea-level rise, changes in temperatures and extreme drought (UNU-EHS 2016). In Vanuatu, where the research that informs this paper was undertaken, scientific studies based on the best available data (PACCSA 2014) suggest a range of climate impacts. Given that annual temperatures have increased in Port Vila since 1950, further warming and an increase in annual temperatures are anticipated. Satellite data indicates sea-level rises around the Vanuatu archipelago of around $6 \mathrm{~mm}$ per year since 1993. By 2030, under a high emissions scenario, the rise in sea level is 
anticipated to be in the range of between 3 and $17 \mathrm{~cm}$. Climate variability, driven by El Niño and La Niña events, have a range of implications on water supplies in Vanuatu, including increases in the frequency and intensity of extreme rainfall that will cause flooding and impact agricultural production. These changes to climate variability are also predicted to have implications for Vanuatu's water quality and availability. Climate variability is also likely to lead to disruptions to seasonality and stress on food crops, thereby impacting on food security. Finally, the climate science linking global warming to cyclones and other extreme weather events is complex. In the Western Pacific region, climate change projections suggest a decrease in the frequency of tropical cyclones but an increase in their intensity.

A recent example of an extreme weather event, or a 'disaster', was Tropical Cyclone Pam, a category five cyclone which struck Vanuatu on 13 March 2015, bringing with it destructive gale-force winds (peaking at around $320 \mathrm{~km} / \mathrm{h}$ ), storm surges and flooding. The centre of the cyclone passed just east of Efate island - which hosts the capital city of Port Vila - destroying homes, schools, health facilities, crops and livestock. Across Vanuatu Cyclone Pam is estimated to have affected around 188,000 people, or $70 \%$ of the population (Government of Vanuatu 2015). In the period after the cyclone, the loss of tree cover led to greater exposure of soil and crops to direct sunlight thereby compounding the effects on food security issues by leading to a prolonged period of drought.

Resilience, now an established 'buzzword' in development (Lewis 2013, 50), is increasingly being used as a programmatic response of governments and international non-government organisations to the issues associated with climate change and disaster responses in Oceania, but with little attention to its conceptual framings. Rather than mere rhetoric, the language of resilience has been mobilised by government and international non-government organisations in Oceania as part of their programmatic responses to disasters and climate change.

Across Oceania representations of disasters, and the post-disaster relief effort, are mediated through a particular hierarchical logic involving the provision of expertise and resourcing to the 'community' as a strategy to strengthen resilience. For instance, the Vanuatu Red Cross, in its program titled 'Together, Becoming Resilient' describes the establishment of Community Disaster and Climate Change Committees (also referred to by using either the local acronym of 'CDCs' or as Committees) made up of local volunteers to 'increase the capacity of vulnerable communities in order to limit the potential damage of the natural event' (Vanuatu Red Cross Society 2014, 2). Here, resilience is deployed as a strategy to overcome the vulnerability of communities in the wake of 'natural' disasters. Using ethnographic research conducted with Community Disaster Committees on Efate Island in Vanuatu in the wake of Tropical Cyclone Pam, this paper problematises disaster responses that see the 'community' as a space to be acted upon by outsiders, or a bounded location in which people will respond in a unified way to the challenges of rebuilding after disaster. The temporal understanding that informs this paper is that disasters, like other discreet events, create a series of opportunities for some people, while at the same time potentially destablising other leaders or groups. In this way, this paper seeks to move beyond the limitations of conceptual framings of community-based resilience in disaster management and climate change into a more considered appraisal of agency, by exploring the 'politics of distribution' in times of disaster (Ferguson 2015). 


\section{The Discourse of Resilience in Oceania}

The etymology of the word resilience is based on the Latin resilio, to bounce, hence the idea that resilience means to bounce back (Manyena et al. 2011; Alexander 2013, 2708). Resilience is a concept that has origins across a diverse set of disciplinary approaches including ecology, psychology, engineering and complex systems analysis (Harrison and Chiroro 2017, 1024; Brown 2014, 108; Dousset and Nayral 2018, 5-7). Resilience has an established conceptual and analytic history in ecology and has long been discussed in terms of the capacity of ecological systems to adapt to change (Folke 2006). More recently these ideas have been used to describe the functioning of global environmental systems in the face of extreme change, such as that caused by changes to climate (Berkes and Ross 2013; Brown 2014). In addition to this disciplinary foundation in ecology, the concept of resilience is also increasingly influenced by academic work in psychology which discusses the resilience of people in the face of traumatic events, as well as work in the behavioural sciences which discusses resilience in the face of social disadvantage (Hegney et al. 2008; Orthner, Jones-Sanpei, and Williamson 2005). Informed by these approaches, advocates for the use of resilience in development approaches argue that it allows for complexity and adaptability in processes and outcomes (Friend and Moench 2013, 102; Goldstien 2011).

In international development literature, the idea of resilience is often espoused as an indicator of positive development where 'more is better' (Barret and Constas 2014, 14626). Policy choices designed to ensure that society can better deal with hazards or shocks are often described as building, or strengthening, resilience (Kelman et al. 2016, 130). The legacy of ecology in the conceptual framing of resilience is evident in the privileging of system stability, or the emphasis on return of a system to the status quo after a shock (Alexander 2013). In the context of climate change and disaster risk reduction, the International Panel on Climate Change has defined resilience as:

The ability of a system and its component parts to anticipate, absorb, accommodate, or recover from the effects of a hazardous event in a timely and efficient manner, including through ensuring the preservation, restoration, or improvement of its essential basic structures and functions. (IPCC 2012)

In this definition, emphasis is placed on the system to efficiently recover from a hazard. How this is done appears to contain potential contradictions between efforts that 'preserve' or 'restore' the existing system, thereby maintaining the status quo, and those designed to 'improve'. These internal contradictions remain foundational to many discussions of resilience as a conceptual and normative framework designed to create better development outcomes (see also Dousset and Nayral 2018, 8).

Across Oceania resilience is often represented as a normative framework that attempts to understand the capacity of individuals and groups to respond to external stresses and shocks: as their capacity to 'bounce back' in response to change (Brown 2014, 108; Harrison and Chiroro 2017, 1024). Numerous climate change reports and disaster preparedness plans highlight the vulnerability of Oceanic countries, particularly low-lying atolls, and discuss strengthening resilience as a strategic development response. For example, in accordance with the established IPCC definition, as reflected in the new Sustainable Development Goals and agreements under the United Nations Framework Convention on Climate Change, the Secretariat for the Pacific Community worked with Oceanic states 
to strengthen 'resilient development' through an integrated approach to climate change and disaster risk reduction (SPC 2017). Following this regional approach, at a national level in Vanuatu, the concept of resilience is regularly deployed in terms of disaster risk reduction and climate change adaptation (see, for example, UNICEF 2015). In these discussions efforts to strengthen resilience are often located at the scale of the community, such that it is the community that must be made resilient so as to withstand disaster and climate change effects. For instance, from 2012 to 2014 a consortium of six national and international development and humanitarian agencies worked together on a program designed to strengthen resilience in 37 communities across Vanuatu in response to climate change and disaster challenges. The program was titled 'Yumi stap redi long klaemet jenis' ('We are ready for climate change'). Funded by the Australian Government, the $\$ 2$ million program developed a 'resilience framework' to strengthen community resilience which, in practical terms, involved working alongside Community Disaster Committees in a range of islands in Vanuatu (Oxfam 2015, 19).

The inclusion of resilience in development discourse has led to a morphing of the original disciplinary foundations of the concept such that it now means different things dependent on the context and, like the 'Yumi stap redi long klaemet jenis' program, is often paired with ideas such as 'community' 'participation' and 'sustainability' (Friend and Moench 2013; Kelman et al. 2016). In the context of the climate change literature, the concept of resilience, as opposed to adaptation or mitigation, offers a way of supporting responses to a change that is generally characterised by increasing uncertainty (Friend and Moench 2013, 103). Critics of resilience have labelled it an 'empty signifier' with mutable meanings that enable it to justify any goal or claim (Weichselgartner and Kelman 2015, 249; Stumpp 2013). It is also apparent that the concepts of 'resilience' and 'vulnerability' are not easily translatable in the vernacular languages of people across Oceania, suggesting that they may be largely alien to people's ontological worldview suggesting important implications for efforts to co-design resilience frameworks (Kelman et al. 2011). In spite of these absences in vernacular languages, the concept of resilience is increasingly used by civil society organisations and local NGOs across Oceania as the basis of claims of Indigenous self-reliance, particularly when coupled with forms of Indigenous knowledge.

Resilience and its twinned concept vulnerability have become dominant discourses in the international literature on disaster and climate change. Vulnerability is not the opposite of resilience as it is often a result of structural inequality within the existing societal system. Rather, they are distinct concepts that are often viewed as overlapping in terms of developmental processes and outcomes (Kelman et al. 2016, 131). There is no problem with the concept of vulnerability per se, and it is important to acknowledge that the real and pressing issues of climate change and disaster in Oceania have particular implications for precarious populations, particularly those impoverished through a lack of access to adequate land (see McDonnell 2017; McDonnell, Allen, and Filer 2017). However, increasingly discourses of vulnerability are deployed in Oceania so as to paint whole countries or people as the passive victims of 'natural' forces, thus occluding the geo-political origins of the climate change crisis.

Vulnerability is often used dialectically to imply a lack of resilience. It is often discussed in the disaster policy literature as a problem to be addressed by strengthening resilience. As a concept, it appears to operate at different conceptual scales than resilience, with 
discourses of vulnerability being attached to whole regions, or nation states. At the time of writing, Vanuatu has, once again, received the dubious honour of being the country with the highest exposure to risk of 'natural hazards' (United Nations University 2016). This analysis of risk is related not only to geophysical 'natural hazards', the effects of which have been exacerbated by climate change, but is also based on an assessment of the country's vulnerability as assessed in terms of 'infrastructure, nutrition, living conditions and economic circumstances' (United Nations University 2016, 8). This analysis labels Vanuatu as a country at risk, and the population as vulnerable. Here the vulnerability of the country is also attached to people who reside within it; it is a definition that is attached to place rather than to any particular personal circumstances of the population (Lewis and Kelman 2010, 193). Such index-based analyses can hide more than they disclose because they fail to measure the structural factors that contribute to differences in vulnerability across the population.

\section{The 'Holy Grail': Efforts to Strengthen Community Resilience}

Considering how resilience is defined and located demonstrates some of its conceptual limitations. In the hierarchical model of disaster management, largely replicated across Oceania, the nation state manages relationships with international donors and INGOs through a specially-established office, in Vanuatu termed the National Disaster Management Office (NDMO). In the context of a disaster, material aid such as shelter and food parcels are directed through the management hierarchy from the NDMO to the provincial level, which on Efate Island is represented by SHEFA Province. From the provincial level, the relief is then directed to the 'community' via the Community Disaster Committee.

Interventions around strengthening resilience are overwhelmingly located at the scale of the community. Much attention has been given in the literature to the supposed 'holy grail' of creating disaster resilient communities (Twigg 2009; Tobin 1999; Magis 2010; Islam, Merrell, and Seitz 2010; Berkes and Ross 2013). Resilient communities are defined as being able to 'withstand extreme geophysical processes and recover rapidly from disasters' (Tobin 1999, 15). For example, in Vanuatu the resilience framework developed by the INGO consortium is now being described as a successful example of community-based adaptation in response to climate change (Webb et al. 2015). The establishment of Community Disaster Committees therefore provides a practical example of attempts by the Vanuatu Government and INGOs' efforts to strengthen community resilience in the face of perceived vulnerability. Since 2010, the Vanuatu Red Cross Society has been engaged in a Disaster Risk Reduction project titled 'Together Becoming Resilient' in various locations across Vanuatu and the Solomon Islands. The aim of the program is, according to the Vanuatu Red Cross, to 'set up Community Disaster Committees in vulnerable communities and train them in order to make the communities less vulnerable and better prepared to manage disasters' (VRCS 2014, 4). The Red Cross has established five CDCs across Efate.

Resilience as a development discourse often speaks to localised agency, while at the same time requiring that communities be acted upon. Resilience frameworks have been critiqued for creating technical-reductionist approaches which draw on 'unchallenged assumptions about the social world' (Weichselgartner and Kelman 2015, 263). For example, the resilience framework developed in Vanuatu by the INGO consortium 
assumes that for communities to be strengthened - made resilient - they must be subjected to specialised outside knowledge. To become resilient, the community is acted upon by experts. Little credence is given in the models to the knowledge and capacity that might be possessed by people living in villages, for instance indigenous knowledge in relation to disaster management. Instead, resilience often imposes its own framework on the existing values, knowledge and agency that are present in local contexts (Weichselgartner and Kelman 2015, 263). In an illustration of the way disasters are 'rendered technical', experts discuss the problems of disaster in technical terms that can be solved by applying expert-driven solutions ( $\mathrm{Li}$ 2011). This is not to suggest that expertise is not useful in the context of disaster responses; rather, it is an attempt to question the assumptions behind these ideas of expertise: Who is seen as 'expert'? And who, by contrast, is viewed as acted upon.

The first period of ethnographic research undertaken for this paper was conducted in two villages located on the central island of Efate in 2015, some eight months after Cyclone Pam. During this period, people on Efate Island, including in these two villages, were also experiencing the effects associated with a prolonged drought. Interviews were conducted with 32 people in these communities, including both the Chairman and all members of the two Committee Disaster Committees (men and women); community members, including those designated as 'vulnerable' during the disaster; chiefs, church leaders as well as men, women and young people. In addition, separate interviews were undertaken with INGO staff, including staff within the Vanuatu Red Cross. The 2015 research was followed by a second and third period of fieldwork conducted in 2017 and 2018, which included a second round of interviews and discussions with Committee and community members, as well as feedback workshops with INGO staff in three of the main organisations located in Port Vila. In total 72 people were interviewed as part of this work. The names of the communities and all participants have been removed. However, where relevant the position held by a particular person is included so as to situate their perspective.

On Efate Island, Committees were established by the Red Cross who completed two days of training in each of the 'vulnerable' communities, the culmination of which was the formation of the Committee. The membership of the Committee is limited to those who attended the training. In each of the locales where the ethnographic research was undertaken, the Red Cross insisted that membership be based on formal gender equality, resulting in an initial committee of five men and five women but with a male Chair. Once Committees are established, a Memorandum of Understanding was signed by Red Cross with the provincial office so as to establish the disaster management hierarchy in relief efforts. A second Memorandum of Understanding was signed between 'the community' and the Red Cross which set out a role of the Committee. However, it was unclear in research conducted who exactly had signed the MOU as the community representatives.

The Vanuatu Government National Disaster Management Office outlines a herculean set of tasks as the 'roles and responsibilities' of the Committees in relation to disaster risk reduction and climate change (see Table 1). These large and variable roles appear to be priority tasks that have been identified as necessary to prepare local populations for climate change adaptation and disasters. It is worth noting that the Committees are entirely voluntary and members receive no payment for any tasks that they assist with. Three separate Committee members describe some of the roles that they performed in the lead up to Cyclone Pam as follows: 
Table 1. Various roles and responsibilities of Community Disaster Committees.

\begin{tabular}{|c|c|}
\hline Climate change roles & $\begin{array}{l}\text { Identify hazards or any changes to your community in relation to weather which } \\
\text { presents a significant risk to your community } \\
\text { Assist other organisations such as NGOs with climate change related work and activities } \\
\text { Advocate and mainstream climate change within the community } \\
\text { Develop a preparedness and climate change plan for the community involving chiefs } \\
\text { and community leaders } \\
\text { Assist in providing climate change information through the community } \\
\text { Collection of data and statistics as required i.e. cropping calendar } \\
\text { Identify hazards and climate change priorities }\end{array}$ \\
\hline $\begin{array}{l}\text { Disaster risk reduction roles: } \\
\text { (1) Planning }\end{array}$ & $\begin{array}{l}\text { Develop a Community-Based Disaster Risk Reduction Plan and a Community Response } \\
\text { Plan } \\
\text { Identify resources available to community members i.e. transport, tools, seed stock, } \\
\text { water containers, etc. } \\
\text { Assist other organisations such as NGOs with disaster related work and activities } \\
\text { Advocate and mainstream disaster risk reduction within the community } \\
\text { Maintain and manage resources donated to the community } \\
\text { Organise meetings regularly to update the community and make any changes to the } \\
\text { contacts if necessary for: } \\
\text { - Plans warning/alerting community members of impending hazards } \\
\text { - Details for evacuation routes to safer areas }\end{array}$ \\
\hline $\begin{array}{l}\text { Disaster risk reduction roles: } \\
\text { (2) In the event of an impending } \\
\text { disaster }\end{array}$ & $\begin{array}{l}\text { Assist with preparation, response and recovery work ahead of a hazard or disaster, } \\
\text { particularly with vulnerable community members }\end{array}$ \\
\hline $\begin{array}{l}\text { Disaster risk reduction roles: } \\
\text { (3) Post-disaster }\end{array}$ & $\begin{array}{l}\text { Undertake initial community assessment after an impact of hazard or extreme event } \\
\text { Assist Rapid Technical Assessment teams with assessments } \\
\text { Assist with vulnerability assessments } \\
\text { Assist vulnerable community members go to safe areas } \\
\text { Assist with distribution of relief supplies } \\
\text { Advise community to 'build back better' by considering extreme weather events } \\
\text { Committee members to participate in the school safety committee }\end{array}$ \\
\hline
\end{tabular}

Source: Vanuatu Government National Disaster Management Office.

My work is to make sure that when the cyclone hits everyone must be inside a good, strong house and make sure that everyone has enough food and water in their houses. Our committee is also supposed to check to make sure that all the houses are in a good condition ahead of the cyclone. We also need to make sure all vulnerable people with special needs-disabled people-are in safe houses so that they are safe when the cyclone hits.

CDCs needed to assess which are the strong, safe houses in the community ahead of the cyclone. Another job that we did was cut down all the trees that could hit houses in the cyclone.

When the cyclone came we were inside the safe houses, we did lots of preparation to make sure that all the houses were safe. Through our work preparing the community only one house was damaged. The community was well prepared when the cyclone hit.

Operating at the frontline of disaster preparedness and management across a wide array of tasks, the Community Disaster Committees established across Vanuatu have been widely credited for saving lives by attending to local preparations in the lead up to the Cyclone Pam (Handmer and Ivenson 2017; CARE 2016, 39). The unpaid labour of Committees is clearly an extremely valuable resource that can help to effectively manage disasters and aid with climate change adaptation projects. However, preliminary research suggests that Committees may operate more successfully in some villages than others. 


\section{The Imagined Community, Efforts to Strengthen Resilience}

Locating resilience at the scale of the community enables a particular description of disaster response and recovery. The Vanuatu Government National Disaster Review Plan describes how communities, led by CDCs, should 'bounce-back' in the post-disaster period:

The best form of recovery is achieved by local communities working together to restore their community back to normal ... [Committees] can identify and manage their resources and outside assistance, and provide status reports and make requests for assistance to the Provincial Disaster Recovery Committee. The plan encourages local communities to work together as disasters effect $[$ sic] all communities. (NDMO 2009, 33)

This problematic statement suggests both that members will collectively 'work together', and that the desired outcome is to return to the status quo that proceeded the disaster. Efforts to strengthen community resilience offer a kind of optimistic 'self-help' strategy supposedly designed to counter the effects of the vulnerabilities of a social group that may otherwise be 'helpless' (Lewis and Kelman 2010, 205). However, no amount of strengthening of community capacity could adequately address the root causes of vulnerability of certain cohorts of people living within villages. Evidence from other disaster contexts, such as those black communities seriously impacted by Hurricane Katrina in New Orleans, suggests that communities are not able to be resilient in the face of long-term governmental neglect and structural violence (Lewis and Kelman 2010, 205). Similarly, given the potential long-terms impacts of climate change in the region, resilient discourse may be setting up Oceanic communities to fail.

The Vanuatu Government Disaster Review Plan also invokes the idea of the homogenous, unified community with shared characteristics, implying the existence of a group of individuals that possess a similar set of values and goals (Agarwal and Gibson 1999, 636). In practice 'communities' do not exist as coherent identities, but rather consist of various groups of people with shifting allegiances. In the context of Indigenous people, idealised visions of shared-community interests are often grafted onto suggestions of collective approaches to 'traditional' governance and resource management that promote environmental stewardship and community harmony. This vision has long been critiqued for failing 'to attend to differences within the communities, and how these differences affect resource management outcomes, local politics and strategic interactions, as well as the possibility of layered alliances that can span multiple levels of politics' (Agarwal and Gibson 1999, 633; see also Green 2016; Li 1996). The imaginary of the collectively governed, egalitarian community is in practice a space of overlapping and contested interests.

The vision of the community as a unified, collective group has long been attractive to policy makers involved in arguing for community-based adaptation and resource management. However, in practice, efforts to strengthen resilience through community-based interventions may fail to pay attention to the power and the political leverage of key actors. In the post-disaster period attention to power is vitally important to ensuring equitable access to disaster relief. Political ecology scholars have challenged the conceptual framings of resilience for failing to pay attention to the role of politics and power relations (Beymer-Farris, Basset, and Bryceson 2012; Ingalls and Steadman 2016). Political ecology research considers how social and environmental conditions are constituted through 
unequal power relations, both global and local, by considering the role played by a panoply of actors operating in 'historically and culturally constructed fields of power' (Peluso and Watts 2001, 25). Post-disaster environments provide an arena for considering the struggles over scarce, relief-related resources. Developing a community-based committee approach may permit some members of the community to benefit while at the same time disadvantaging others.

Building on the challenges posed by political ecology theorists to concepts of resilience, and on the work of Ferguson (2015) on the 'politics of distribution' I seek to describe the way villages are governed by existing institutions and actors who utilise their own agency in ways that either support, or circumscribe, 'top-down' national approaches to disaster distribution. The two villages that form the basis of this research present a study in contrasts: in one village (termed 'village A') the work of the Community Disaster Committee is highly regarded by chiefs, church leaders, women leaders, youth, and other village members. In the other village (termed 'village B'), the work of the Committee has been repeatedly undermined, and the efforts of the Chairman and other members of the Committee have been largely discredited.

In the village where the Committee operated well (village A) the members of the Committee highlighted the importance of the support of chiefs and church leaders in establishing and recognising the role of the Committee. The Committee Chairman describes how the senior village chief announced the composition of the Committee and the role that the Committee would play during a number of church services; 'After the CDC was formed the chief announced my role as the Chairman, and the other members of the Committee, in church. He told everyone that they had to support the work of the Committee'. This early statement of support meant that the Chairman operated with the imprimatur of the Chief, supported by both local chiefly and religious institutions.

\section{Other Dark Sides of Resilience: The Politics of Disaster Distribution}

Resilience discourse can work to obscure the structural power asymmetries associated with disasters and climate change. In her work on the applications of resilience to climate change and development issues, Brown (2012) demonstrates that overall the analysis of resilience often contributes to maintaining the status quo, rather than any substantial structural change. The approach by the Resilience Alliance which is framed in terms of creating a 'return to normal' society after a shock (see, for example, Folke 2006) has been critiqued on the grounds that structural vulnerability is an established state of most societies, such that gender, racial and ethnic inequalities are often the established norm (Kelman et al. 2016, 137). This analysis describes what is termed the 'dark side of resilience' the way in which systems are maintained even where they create undesirable outcomes (Mitchell and Harris 2012, 5). Galliard's (2010) discussion of the use of resilience and vulnerability as conceptual framings for understanding disasters suggest that while resilience is able to highlight existing capacities, it does this at the cost of considering the root causes of vulnerability. In the context of these critiques, attempts to strengthen resilience at the local level must consider questions of institutional governance, as well as the unequal distribution of power and resources within the space of the 'community'.

Efforts focussing on strengthening community-based resilience in times of disaster must pay particular attention to power and politics within the space of the imagined 
community. Relief efforts operate as a new form of social transfer which, like the presence of cash transfer systems in certain countries in Africa, may bring with them a particular 'politics of distribution' (Ferguson 2015, 10). These new welfare systems, and particularly those of South Africa and Namibia, are accompanied by a 'the exhaustion of older forms of politics and [the] vital possibilities for new ones' (Ferguson 2015, 14). Like cash transfers, relief after disaster is provided without any requirement of labour, thereby creating a particular 'politics of distribution'.

Exploring the politics of distribution, it is evident that access to resources post-disaster became a central claim to status and authority within local villages. Ferguson suggests that the politics of distribution is apparent in 'new kinds of political claim making' (Ferguson $2015,14)$. More specifically, he describes the politics of distribution as 'the general processes of distribution as they unfold in contemporary societies, and about the sorts of binding claims and counter-claims that can be made about these processes' (Ferguson $2015,20)$. In the aftermath of the cyclone, the claims of Community Disaster Committees to represent the legitimate community structure were either supported or contested by powerful men already embedded in alternative local authority structures. Assuming the position as Chairman of a CDC became a position of considerable power over scarce relief resources. In terms of the stipulated role of CDCs, the Chairman has a degree of access and control over the management of relief efforts at the local scale of the 'community'.

In the post-disaster context, the position as a Chairman becomes one of elevated status, which can be supported by the existing leadership and subsumed into already existing power structures, as occurred in village A. Alternatively, Chairman and committee members can be viewed as a rival source of authority by local leadership, as occurred in village B. In this context, Community Disaster Committees can be viewed as externally imposed on to communities, operating as a challenge to the existing roles and responsibilities of chiefs. The Chairman of the CDC of village B describes the political contestations surrounding the distribution of goods after Cyclone Pam:

Some chiefs keep pushing to take over the Committee. When the relief supplies came all the men wanted to be involved. They were cross with me, they came and talked strongly to me. I was in the chief's farea sharing the food and they would come and yell at me and I just said, 'I am doing my job'.

Here the resources made available in the period post-cyclone provided a channel for the politics of disaster distribution - the contestations of status and authority accompanied the distributions of funds, material goods and other offers of assistance at the local scale within the 'community'. The politics of distribution is made manifest in the series of political claims and counter-claims about who is best able to represent the community so as to access relief supplies.

At the local level, the experience of both the disaster and the relief effort is directly related to how individuals and family groups are positioned in relation to supportive social relations as well as economic and political agency (Nadiruzzaman and Wrathall 2015, 196; Watts and Bohle 1993). Villages are dominated by localised leadership and power structures. Gender, age, local claims to authority such as through chiefly status or other leadership positions, wealth and status all structure the relative positioning of individuals and families at the local level. Social relationships and power structures 
have a significant impact on how disaster supplies are distributed. In Vanuatu, claims to authority over the allocation and distribution of resources were contested between local customary institutions, provincial agencies and village-based Community Disaster Committees. In particular, various actors demonstrated their own agency by directly accessing disaster relief, thereby bypassing the disaster management hierarchy. In village $B$, the ferocity of the politics around the distribution of disaster relief was enhanced by the sense of an imposed structure operating as an alternative to existing institutional authority as represented by the chiefs and churches. A local chief offers an account of the politics that surrounded the work of the Committee in village B:

With the Cyclone and the relief effort there was a lot of politics. Some men wanted to overrule the Committee. Some chiefs went directly to Shefa Province to receive the distributions but Shefa told them that they were not Committee members and they had to go back to the island.

In this account, the local provincial distribution structure was forcefully adhering to the operational disaster-management hierarchy, by reasserting the role of the CDCs as the legitimate community representatives. It also demonstrates the repeated challenges and counter-claims made by powerful men to the structure imposed by the disaster management hierarchy that positioned the Committee as the legitimate community representatives.

Political ecologists have offered a pointed critique of resilience framings as being 'naïve about, or perhaps even unable to engage with, the workings of power' (Ingalls and Steadman 2016, 1; Walsh-Dilley, Wolford, and McCarthy 2013). While offering the intuitive appeal in highlighting strengths of communities in the face of extreme change, resilience has been critiqued for its failure to consider how this capacity is contingent on political and institutional arrangements (Brown 2014, 109), such that the agency of a group or individual is configured by gender, race, class dimensions. These issues have prompted political ecologists to ask: 'resilience for what and for whom' (Friend and Moench 2013, 104; Brown 2014, 109), to which it is important to add: resilience as defined by whom, and for what political purpose?

Ethnographic accounts of relief distribution contained in this paper suggest that the work to strengthen community-based approaches in disaster management and climate change adaptation can assume a simplistic and idealised vision of people working together for a common good. These assumptions are particularly problematic in a post-disaster context where people's livelihoods are threatened and where existing institutional arrangements and power structures may be challenged. Ideas of a unified, homogeneous 'community' fail to take into account localised expressions of social structures and power relations embedded in ideas of gender, status and authority, and the difference and diversity amongst people. Instead, the concept of community so regularly deployed in policy praxis as a way of managing disaster and climate change adaptation must be understood 'as a political association formed through processes of political and cultural creation and imagination - the generation of meaning in the contexts of unequal power' (Roseberry $1989,14)$. The space of the 'community', so reified in disaster-management hierarchies, is itself an imagined illusion.

In the immediate aftermath of the cyclone, the politics of distribution highlight the contested spaces of the community and the alternate claims made by powerful actors to relief 
resources. These actors strategically tried to pas bihaen (pass behind) the Committee to directly access relief resources. The phrase, however, also implies a subverting of the established process for distributing resources. Used in terms of marriage, for example, the phrase 'pas bihaen' means to have extra-marital affairs. Amidst the politics of distribution, the Chairman and committee members of village B were left with the unenviable position of trying to defend their position as the representative of the community in the disaster management hierarchy. Here the Chairman describes his position, at the time:

We signed an MOU with Red Cross to say that after any disaster we would manage the distribution in the community. But some people wanted to pas bihaen.

Donors want to support people, so they provided resources directly to people. Some men will just distribute and tell me what they have done after. The Committee distributed the food and clothing from our Australian friends, but for lots of the other things other men just distributed them.

The big problem with our work is that all other men pas bihaen the Committee.

We wrote letters to Port Vila or to Shefa Province to make a request for supplies needed to help with the recovery-things like a chainsaw and generator-but the generator never came and the chainsaw just pas bihaen. I had to get the chainsaw back from the people who had taken it.

Now I'm trying to place things that are donated in the clinic so that they don't get taken by the chiefs. Chiefs, individuals and church members have all been trying to pas bihaen to get clothes, food.

In this discussion, the Chairman makes his claim to authority to manage distributions by referencing the work of international agencies and their processes in legitimating the role of the Committee as the legitimate community structure. The 'we' of this quote is not the community but rather it is the Committee members themselves who have signed onto the Memoranda of Understanding. In the face of this imposed community structure, existing male leaders have chosen to pas bihaen, strategically engaging in challenging the authority of the Committee by making their own claims to accessing, managing and facilitating relief efforts. In this way, local powerful men were enacting an alternative idea of the 'community', one in which they are positioned as the authority figures who can lay claim to the masculine status associated with managing the distribution of resources to their family and kinship groups.

As well as undermining the operations of the Committee externally - by accessing relief efforts directly - the operations of the Community Disaster Committee in village B were also undermined by critiques from other people living within the village locale. The idea of the Committee as an imposed structure became evident in the many critiques made by local chiefs, women and young people of the work of the Committee. Within the village in the post-disaster period, many people began to challenge the behaviour of the Committee, and key Committee members, on moral grounds associated with failing to demonstrate an understanding of kastom. Kastom in this context can be understood as the 'ways of place': the correct and proper way of behaving as a person of the place, a manples. Specifically, the Committee was critiqued for not upholding the locally-privileged kastom moral code of sharing the distribution of goods amongst kin and family. Many of the same chiefs who had been involved in trying to pas bihaen the Committee to 
access aid were also involved in critiquing the efforts of the Committee to the point where Committee membership began to decline. In village $B$, the female members left the Committee due to the accusations from powerful men that surrounded the distribution of food, clothes and other material goods.

The outcome of these repeated challenges to the authority of the Community Disaster Committee in village $B$ was that the Committee was no longer able to perform its role and functions. In the post-disaster period, in several instances where clothes and other material goods were distributed, chiefs and other villagers from village $B$ decided that the distribution would be managed by the Committee from village $A$, rather than their own CDC. This had two effects. First, it further exacerbated the rivalry between the two villages, which created a regional discussion around the politics of distribution with suggestions made that one village benefitted significantly more than the other from relief efforts. Second, even more concerning, was the human cost in terms of reputational damage as well as the breakdown in family and kinship ties, associated with the failure of the Committee in village B to secure the support of powerful chief and church leaders.

As the relief effort progressed, accusations were repeatedly made that the Committee members in village B were hiding food or acting selfishly in the interests of their own families, rather than properly managing the distribution of goods for the benefits of all members of the village. Regardless of whether these accusations were true, they served to delegitimise the Committee on the basis that they were not upholding local kastom values. The challenges of powerful men to the operations of the Committee were deemed morally appropriate by many village members, on the basis that the Committee had not performed its distribution functions in accordance with the proper practice of kastom. These challenges also created a significant human cost to the members, and particularly female members, of the Committee, who were deemed to have managed the distribution of relief efforts in ways that were self-interested, and who were subsequently widely regarded by other Community members as immoral and unfair. The second and third periods of fieldwork conducted as part of this research starkly illustrated one aspect of this human cost: the Chairman of the village B Committee is no longer living in the village as a result of the reputational damage of being involved in the relief distribution process. Beyond the Chairman many of the members of the original CDC no longer want to be involved in Committee work.

\section{Conclusion: Resilience for Whom?}

As externally imposed structures, the success of Community Disaster Committees appears to depend largely on whether they are accepted by existing power structures already located within the village. Where they are not carefully established, CDCs can exacerbate tensions within villages (particularly on the basis of leadership, status and gender), as well as rivalry between villages. As we have seen, Committees can become embroiled in a politics of disaster distribution: this emerges as a set of political claims and counter-claims about who is best able to represent the community so as to control access to and distribute relief supplies.

Serious attention needs to be paid to this localised politics of distribution as there can be significant implications for individual Committee members; the same people who have personally experienced disaster can potentially be further victimised by others who wish 
to challenge the role of the Community Disaster Committee as the legitimate representative of the 'community'. There is a very real human cost to disaster and climate change adaptation programming that fails to pay attention to the operation of power at the local scale. In answering the question 'resilience for whom?', we need to ask a further question: when resilience is based on a model of collective community working together to 'bounce back' are there some people disadvantaged, or bearing additional costs? And if so, how are these costs accounted for in attempts to strengthen resilience? There is a danger that without attention to power, strengthening the resilience of one group may come at the cost of another. In this way, community-based approaches to strengthening resilience may, in practice, actually perpetuate vulnerabilities.

Resilience is the discourse of development in which 'more is better'. It is aimed squarely at an audience of international donors, with policy developed to attend to an international, rather than a local audience. Resilience continues to be defined by an external audience of INGOs, government and academics with little reference to the actual population that have experienced either disaster or the ongoing effects of climate change. It is designed to counter international assessments of 'vulnerability', whether based on risk or supposed individual characteristics such as being female, young, old or disabled. These designations of vulnerability fail to pay attention to localised structures based on family and kin, cultural norms and existing institutional arrangements. Efforts to strengthen resilience or address vulnerability must pay more attention to power, institutional and structural arrangements. In Oceania, efforts to strengthen resilience must be reoriented so as to involve the local affected population in defining aspects of resilience that are meaningful in their lives and livelihoods, as they are increasingly affected by 'natural' disasters and climate change.

Resilience narratives that are designed as community-based approaches to disaster management or climate change adaptation, flatten the local scale into a homogenous group in which people are supposed to work together around a shared set of values. Approaches to community-based disaster management and climate change adaptation also position 'the community' as a space to be acted on by external technical knowledge, strengthened by engagement with external expertise. Rather than viewing the community as a romanticised space of resilience, the ethnographic research that informs this paper illustrates how key actors influenced decision-making over the distribution of aid resources, post-disaster. Establishing Community Disaster Committees without reference to existing institutional arrangements, or attention to local politics and power, created contestation over the resources that were distributed in the immediate period after Tropical Cyclone Pam.

Rather than establishing new externally imposed structures, another model of disaster distribution at the local level could involve building from existing institutional arrangements. Programming that wishes to address gender equity in terms of distribution could, for example, work in partnership alongside existing women's church groups. These partnerships would need to be built over time and, would inevitably, involve more than just two days of training in each village area. Existing church and chiefly institutions are also the subject of unequal power and politics. However, they are also institutions that have a particular function and form, and that operate with an existing mandate.

Discussions of resilience can privilege ideas of recovery, rather than any fundamental change to the system that addresses the causes of the problem. They can thereby create 
a conservative narrative that allows for the continuance of unsustainable practices (Adger, Brown, and Nelson 2011; Barnett and O’Neill 2010). Returning to the question posed by political ecology theorists, we need more awareness in disaster and climate change policy documents around the politics of resilience. We must ask: resilience for whom? Resilience offers a supposedly apolitical conceptual lens. However, the danger of this framing is that it can obscure some of global structural inequalities associated with climate change and disaster.

The most effective way of ensuring the resilience of people in Oceania to the threats posed by climate change and disaster is to stop global carbon emissions. This geo-political solution is surely the root cause of climate-related vulnerabilities (Ribot 2014). By contrast, the language of resilience is, as described in this paper, locates risks and solutions at the scale of the community: as a strategy designed to address the vulnerabilities of particular communities. At its most problematic, the concept of resilience offers a morally-loaded discourse in which the responsibility for the response to disasters can be placed on the individual or community, with the expectation that they will 'bounce back'. At the same time, removing responsibility from the states or the global international community of polluters who are contributing to issues of climate change and exacerbating the intensity of 'disasters' in Oceania. In its failure to attend to global structural inequalities, resilience as a conceptual framing can place the burden of disaster management and climate change adaptation on the same Oceanic populations that are already disproportionately burdened by the impacts of climate change. There is a representational politics implicit to determinations of who is able to be resilient and how resilience is made manifest, and it is this that we must carefully consider in approaches that are designed to strengthen communitybased resilience to disasters or climate change.

\section{Disclosure Statement}

No potential conflict of interest was reported by the author.

\section{References}

350 Pacific. 2013. We are Not Drowning We are Fighting. https://350.org/350-pacific-we-are-notdrowning-we-are-fighting/.

Adger, W., K. Brown, and D. Nelson. 2011. "Resilience Implications of Policy Responses to Climate Change." Wiley Interdisciplinary Reviews: Climate Change 2: 757-766.

Agarwal, A., and C. Gibson. 1999. "Enchantment and Disenchantment: The Role of the Community in Natural Resource Conservation.” World Development 27 (4): 629-649.

Alexander, D. E. 2013. "Resilience and Disaster Risk Reduction: An Etymological Journey." Natural Hazards and Earth System Sciences 13: 2707-2716.

Barnett, J., and S. O’Neill. 2010. “Maladaptation.” Global Environmental Change 20: 211-213.

Barret, C., and M. Constas. 2014. "Towards a Theory of Resilience for International Development Applications." Proceedings of the National Academy of Sciences 111 (40): 14625-14630.

Berkes, F., and H. Ross. 2013. "Community Resilience: Towards an Integrated Approach." Society and Natural Resources 26 (1): 5-20.

Beymer-Farris, B., T. Basset, and I. Bryceson. 2012. "Promises and Pitfalls of Adaptive Management and Resilience Thinking: The Lens of Political Ecology." In Resilience in the Cultural Landscape, edited by T. Pleininger and C. Bieling, 283-299. Cambridge: Cambridge University Press. 
Brown, K. 2012. "Policy Discourses of Resilience." In Climate Change and the Crisis of Capitalism: A Chance to Reclaim Self, Society and Nature, edited by Mark Pelling, David Manuel-Navarrete and Michael Redclift, 1-14. Routledge: London.

Brown, K. 2014. "Global Environmental Change I: A Social Turn for Resilience?" Progress in Human Geography 38 (1): 107-117.

CARE. 2016. Does Gender Responsive Disaster Risk Reduction Make A Difference: A Comparative Study of Category Five Tropical Cyclone Pam in Vanuatu. Port Vila: Care Vanuatu.

Dousset, L., and M. Nayral. 2018. "Introduction: Resistance and Resilience." In Pacific Realities: Changing Perspectives on Resilience and Resistance, edited by L. Dousset and M. Nayral, 1-22. Oxford: Berghahn.

Ferguson, James. 2015. Give a Man a Fish: Reflections on the New Politics of Distribution. Durham: Duke University Press.

Folke, C. 2006. "Resilience: The Emergence of a Perspective for Social-Ecological Systems Analyses." Global Environmental Change 16: 253-267.

Friend, R., and M. Moench. 2013. "What is the Purpose of Urban Climate Resilience? Implications for Addressing Poverty and Vulnerability." Urban Climate 6: 98-113.

Galliard, J. 2010. "Vulnerability, Capacity and Resilience: Perspectives for Climate and Development Policy." Journal of International Development 22: 218-232.

Goldstien, B. 2011. Collective Resilience: Moving Through Crisis to Opportunity. London: MIT Press.

Government of Vanuatu. 2015. Humanitarian Action Plan: Tropical Cyclone Pam, 1 May 2015. Port Vila: Vanuatu Government.

Green, K. 2016. "A Political Ecology of Scaling: Struggles over Power, Land and Authority." Geoforum; Journal of Physical, Human, and Regional Geosciences 74: 88-97.

Handmer, J., and H. Iveson. 2017. "Cyclone Pam in Vanuatu: Learning from the Low Death Toll." Australian Journal of Emergency Management 32 (2).

Harrison, E., and C. Chiroro. 2017. "Differentiated Legitimacy, Differentiated Resilience: Beyond the Natural in 'Natural Disasters'." The Journal of Peasant Studies 44 (5): 1022-1042.

Hegney, D., P. Ross, C. Rogers-Clark, E. King, E. Buikstra, A. Wtson-Luke, K. Mclachlan, and L. Stallard. 2008. Building Resilience in Rural Communities Toolkit. University of Queensland: Toowoomba.

Ingalls, M., and R. Steadman. 2016. “The Power Problematic: Exploring the Uncertain Terrains of Political Ecology and the Resilience Framework." Ecology and Society 21 (1): 1-11.

International Panel on Climate Change (IPCC). 2012. "Glossary of Terms. Managing the Risks of Extreme Events and Disasters to Advance Climate Change Adaptation." In A Special Report of Working Groups I and II of the Intergovernmental Panel on Climate Change (IPCC), edited by C. B. Field, V. Barros, T. F. Stocker, D. Qin, D. J. Dokken, K. L. Ebi, M. D. Mastrandrea, K. J. Mach, G.-K. Plattner, S. K. Allen, M. Tignor, and P. M. Midgley, 555-564. Cambridge: Cambridge University Press.

Islam, T., W. Merrell, and W. Seitz. 2010. "Galveston Futures: Developing a Disaster Resilient Community." Journal of Geography and Regional Planning 3 (1): 1-7.

Kelman, I. 2018. "Islands of Vulnerability and Resilience: Manufactured Stereotypes?" Area 2018, 1-8.

Kelman, I., J. Lewis, J. C. Galliard, and J. Mercer. 2011. "Participatory Action Research for Dealing with Disasters on Islands." Island Studies Journal 6 (1): 59-86.

Kelman, I., J. Lewis, J. C. Galliard, and J. Mercer. 2016. "Learning from the History of Disaster Vulnerability and Resilience Research and Practice for Climate Change.” Natural Hazards 82 (1): 129-143.

Lewis, J. 2013. “Some Realities of Resilience: A Case-Study of Wittenberge.” Disaster Prevention and Management: An International Journal 22 (1): 48-62.

Lewis, J., and I. Kelman. 2010. "Places, People and Perpetuity: Community Capacities in Ecologies of Catastrophe." ACME: An International E-Journal for Critical Geographies 9 (2): 191-220.

Li, T. 1996. "Images of Community: Discourse and Strategy in Property Relations." Development and Change 27 (3): 501-527. 
Li, T. 2011. "Rendering Society Technical: Government Through Community and the Ethnographic Turn at the World Bank in Indonesia." In Adventures in Aidland: The Anthropology of Professionals in International Development, edited by David Mosse, 57-80. Oxford: Berghahn.

Magis, K. 2010. "Community Resilience: An Indicator of Social Sustainability." Society of Natural Resources 23 (5): 401-416.

Manyena, S., G. O’Brien, P. O’Keefe, and J. Rose. 2011. "Disaster Resilience a Bounce Back or Bounce Forward Ability?” Local Environment 16 (5): 417-424.

McDonnell, S. 2017. "The Challenges of Regulation: Charting Urban Land Grabbing by Political Elites." In Kastom, Property, and Ideology: Land Transformations in Melanesia, edited by Siobhan McDonnell, Matthew Allen, and Colin Filer, 283-304. Canberra: ANU Press.

McDonnell, S., M. Allen, and C. Filer, eds. 2017. Kastom, Property, and Ideology: Land Transformations in Melanesia. Canberra: ANU Press.

Mitchell, T., and K. Harris. 2012. Resilience: A Risk Management Approach. Overseas Development Institute (ODI) Background Note. London: ODI.

Nadiruzzaman, M., and D. Wrathall. 2015. "Participatory Exclusion - Cyclone Sidr and its Aftermath." Geoforum 64: 196-204.

National Disaster Management Office, Republic of Vanuatu (NDMO). 2009. National Disaster Plan Review October 2009-October 2010. Port Vila: NDMO.

Orthner, D., H. Jones-Sanpei, and S. Williamson. 2005. "The Resilience and Strengths of LowIncome Families." Family Relations 53 (2): 159-167.

Oxfam International. 2015. Yumi Stap Redi Long Klaemet Jenis: Lessons from the Vanuatu NGO Climate Change Adaptation Program. Melbourne: Oxfam.

Pacific-Australian Climate Change Science Adaptation Planning (PACCASP). 2014. Climate Variability, Extremes and Change in the Western Tropical Pacific: New Science and Updated Country Reports 2014. Canberra: CSIRO.

Peluso, N., and M. Watts, eds. 2001. Violent Environments. Ithaca: Cornell University Press.

Ribot, J. 2014. "Cause and Response: Vulnerability and Climate in the Anthropocene." The Journal of Peasant Studies 41 (5): 667-705.

Roseberry, W. 1989. Anthropologies and Histories: Essays in Culture, History and Political Economy. London: Rutgers.

Secretariat of the Pacific Community (SPC). 2017. Framework for Resilient Development in the Pacific: An Integrated Approach to Address Climate Change and Disaster Disk Management (FRDP) 2017-2030. Suva: SPC.

Stumpp, E. 2013. "New in Town? On Resilience and 'Resilient Cities'." Cities 32: 164-166.

Tobin, G. A. 1999. "Sustainability and Community Resilience: The Holy Grail of Hazards Planning?” Global Environmental Change Part B: Environmental Hazards 1 (1): 13-25.

Twigg, J. 2009. Characteristics of a Disaster Resilient Community: A Guidance Note. Disaster Risk Reduction NGO Interagency Group. London, UK: DFID.

United Nations International Children's Emergency Fund (UNICEF). 2015. Community Resilience and Coping with Climate Change and Natural Disasters in Vanuatu: Evaluation Report.

United Nations University. 2016. World Risk Report. Berlin: United Nations University.

United Nations University Environmental Hazard Survey (UNU-EHS). 2016. World Risk Report 2016. Tokyo: United Nations University.

Vanuatu Red Cross Society (VRCS). 2014. Community Based Disaster Risk Reduction: Handbook for Local Facilitator. Port Vila: VRCS.

Walsh-Dilley, M., W. Wolford, and J. McCarthy. 2013. Rights for Resilience: Bringing Power, Rights and Agency into the Resilience Framework. Washington, DC: Oxfam America.

Watts, M., and H. Bohle. 1993. "The Space of Vulnerability: The Causal Structure of Hunger and Famine." Progress in Human Geography 17 (1): 43-67.

Webb, J., D. Vorbach, E. Boydell, R. McNaught, and C. Sterret. 2015. "Tools for CBA: Lessons from NGO Collaboration in Vanuatu." Coastal Management 43 (4): 407-423.

Weichselgartner, J., and I. Kelman. 2015. "Geographies of Resilience: Challenges and Opportunities of a Descriptive Concept.” Progress in Human Geography 39 (3): 249-267. 